\title{
Rights and Responsibilities
}

\section{on the Home Planet}

\author{
Holmes Rolston, $\mathbf{I I I}^{\dagger}$
}

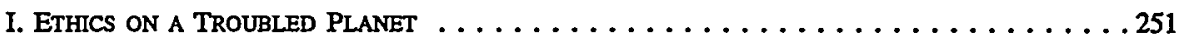

II. Human Rights: A Troublesome Paradigm for Earth Ethics $\ldots \ldots \ldots \ldots \ldots 253$

A. Rights in Western Ethics and Law . . . . . . . . . . . . . . . . 253

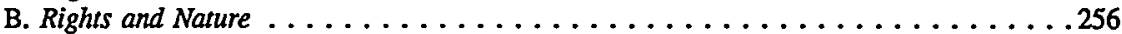

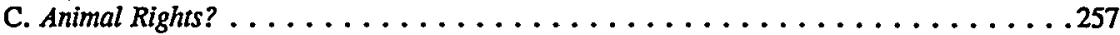

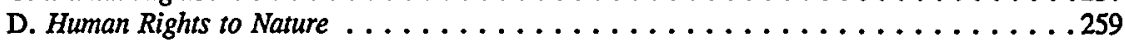

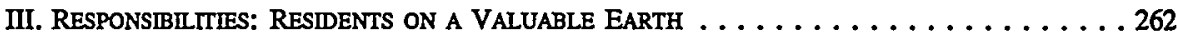

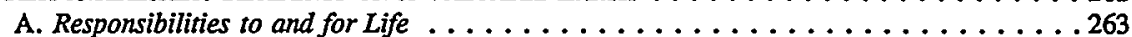

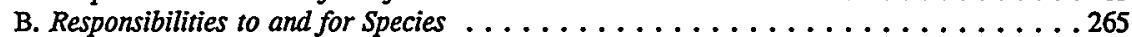

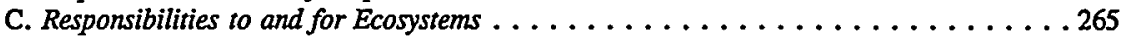

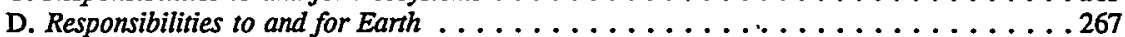

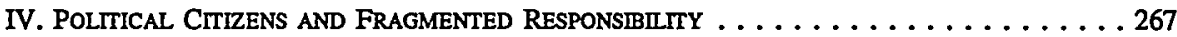

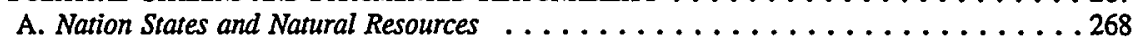

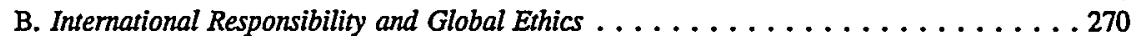

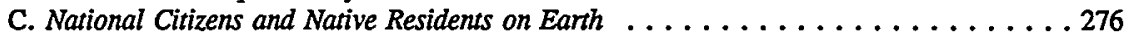

V. Ethics on the Home Planet $\ldots \ldots \ldots \ldots \ldots \ldots \ldots \ldots \ldots \ldots \ldots \ldots \ldots \ldots$

\section{Ethics on a Troubled Planet}

Throughout most of this century, we have worried that we would destroy ourselves in interhuman conflict. Fortunately, that fear has subsided. Unfortunately, it is rapidly being replaced by a new one. In the upcoming century, we will worry that we may destroy our planet and ourselves with it. We are approaching a new millennium. The challenge of the current millennium has been to pass from the medieval to the modern world, building modern cultures and nations in an explosion of technological development. The challenge of the next millennium will be to contain those cultures within the carrying capacity of the larger community of life on our home planet. For many millennia, diverse combinations of nature ${ }^{1}$ and culture worked well

$\dagger$ University Distinguished Professor of Philosophy, Colorado State University.

1. In this paper, "nature* refers to natural forces operating independently of deliberate human activity, that is, spontaneous or wild nature. Human cultural processes interrupt such natural forces. Little pristine nature remains, though some marine areas, Antarctica, or designated wildernesses can approximate it. At the same time, spontaneous natural forces everywhere permeate the cultures superimposed on them: winds blow, rains come, acorns grow into oaks and make acorns, birds nest and migrate, forest humus decays, leaves photosynthesize, crops grow, and so on. Global natural forces - the ocean currents, the changing seasons, photosynthesis and oxygen balance, regional ecosystems - though not beyond the adverse affects of human action, still proceed spontaneously.

Spontaneous nature exists within humans in the form of biochemical processes that proceed without deliberation, but the most characteristic property of humans is to build cultures, which typically rebuild 
enough but no longer. In the last century, our modern cultures began to threaten the stability, beauty, and integrity of Earth, thereby threatening the cultures superimposed on the Earth. On our present course, much of the integrity of the natural world will be destroyed within the next century. To continue the developmental pace of the last century for another millennium will produce sure disaster. If humans are to be true to our species' epithet, "the wise species" must behave with appropriate respect for life. Such behavior necessarily will involve an interhuman ethics. Will it also involve an interspecies ethics, in which the only moral species discovers that all the others, though not moral agents, deserve moral consideration? Will it involve an Earth ethics that discovers a global sense of human obligation to this inhabited planet, the only such planet we know?

Ethics in the modern West has consisted almost entirely of interhuman ethics: finding a way for persons to relate morally to other persons. This limited approach has focused on how humans fit into their communities, and has ignored how humans fit into the natural world. Now that the destructive effects of human cultural development have begun to take their toll on the natural world, we need an environmental ethics, one that can find a satisfactory fit for humans in the larger communities of fauna and flora. ${ }^{2}$ To develop an ethical theory, humanity must combine argument and reflection, exploring an alternative worldview that is not so much rights-based as responsibility-based, one that is biocentric and not simply anthropocentric.

This paper examines rights and responsibilities in an Earth ethics. It seeks

spontaneous nature, intentionally redirecting the course of nature to human utility. As Aristotle put it, humans build a polis, a political community with transmissible culture and technology. See ARISTOTLE, infra note 11 . Humans arrive in the world rather unfinished by nature, and cultural education and formation, coupled with active career choice, largely complete our identity. By contrast, identities in nonhumans are genetically determined. In short, human nature is to be artificial, or cultured.

In one sense nothing that humans do breaks any laws of nature; we simply rearrange natural forces to our benefit. In this sense, a rocket is as natural as an oak tree, Manhattan as natural as Yellowstone Park. But this concept is not helpful in the present analysis, since an Earth destroyed by humans would be as natural an event as an Earth with several billion years of natural history before humans arrived, or an Earth carefully conserved by humans thereafter. For further analysis see HOLMES ROLSTON, III, Environmental Ethics 32-44 (1988); Holmes Rolston, III, PHILOSOPHY GoNe Wild 30-52 (1986) [hereinafter RoLSTON, PHILOSOPHY].

2. The most important systematic works on environmental ethics are the following: ROBIN ATTFIELD, THE ETHICS OF ENVIRONMENTAL CONCERN (1991); ANDREW BRENNAN, THINKING ABOUT NATURE: AN INVESTIGATION OF NATURE, VALUE AND ECOLOGY (1988); BILI DEVALl \& GEORGE SESSIONS, DEEP ECOLOGY (1985); EUGENE C. HARGROVE, FOUNDATIONS OF ENVIRONMENTAL ETHICS (1989); LAWRENCE E. JoHNSON, A MORALly DEEP WORLD: AN EsSAY ON MORAL SIGNIFICANCE AND ENVIRONMENTAL. ETHICS (1991); FREYA MATTHEWS, THE ECOLOGICAL SELF (1991); ARNE NaESs, Ecology, COMMUNITY, AND LIFESTYLE: OUTLINE OF AN ECOSOPHY (David Rothenberg trans., 8th ed. 1989); BRYAN G. NORTON, TOWARD UNITY AMONG ENVIRONMENTALISTS (1991); VAN RENSSELAER POTTER, GLOBAL BIOETHICS: BUILDNG ON THE LEOPOLD LEGACY (1988); ROLSTON, ENVIRONMENTAL ETHICS, supra note 1; RoLSTON, PHILOSOPHY, supra note 1; MARK SAGOFF, THE ECONOMY OF THE EARTH: PHILOSOPHY, LAW, AND THE ENVIRONMENT (1988); CHRISTOPHER D. STONE, EARTH AND OTHER ETHICS (1987); PAUl W. TAylor, Respect For Nature (1986); Peter S. Wenz, ENVIRONMENTAL JusticB (1988). 
to balance appropriately ethics and biology, law and natural history, nature and culture, human and natural values. Part II explores whether the concept of rights, so important in recent Western ethics and law, is useful in conserving nature, and concludes that the concept of rights has limited usefulness in this respect. Part III examines human responsibility to protect natural values, including the responsibilities to protect life, species, ecosystems and, ultimately, Earth as the most valuable life-producing system. Part IV finds that political citizenship tends to fragment these Earth-oriented responsibilities and concludes that we need to be residents of Earth as much as citizens of nations, and we need to create international conventions that integrate responsibilities and begin to move humanity toward an Earth ethics. Part V concludes that we must develop an Earth ethics in order to elevate urgent ecological concerns to the forefront of human thought and action.

\section{Human Rights: A Troublesome Paradigm for EARTh Ethics}

\section{A. Rights in Western Ethics and Law}

Earth is a planet with several billion years worth of biology. Western ethics, however, developed long before the science of modern biology arose to describe these millennia of natural history and the processes by which life once developed and still continues to develop. After the development of Darwinian biology, philosophers and legal ethicists attempted in vain to construct a naturalistic ethic, using the facts of biology as a basis for drawing conclusions about what humans ought to do. Convinced that they had committed a "naturalistic fallacy, ${ }^{13}$ philosophers have since disregarded biology. ${ }^{4}$ Even those philosophers who might have accepted limited bioethical constructs, such as the field of medical ethics, were loathe to apply ethics to nonhuman biology. Many felt that nature itself is value free and therefore cannot be the object of human duty; one cannot be obliged to protect a valueless thing. ${ }^{5}$ Ethics therefore developed into an anthropocentric discipline.

3. David Hume regarded it a logical fallacy to argue from facts, such as biology, to duties in ethics, from "is" language to "ought" language. David HUME, A TREATISE OF HUMAN NATURE 469 (L.A. SelbyBigge ed., Clarendon Press 1978) (1st ed. 1739). G.E. Moore claimed that any who derive morality from the natural world commit the "naturalistic fallacy." GEORGE EDWARD MOORE, PRINCIPIA ETHICA 20 (1903).

4. See Michael RuSe, Taking Darwin Seriously 67-102 (1986) (tracing these attempts). Ruse hopes to recover an evolutionary ethics.

5. William James, in an influential and representative statement, portrays an utterly valueless world, which becomes valuable only when humans arrive:

Conceive yourself, if possible, suddenly stripped of all the emotion with which your world now inspires you, and try to imagine it as it exists, purely by itself, without your favorable or unfavorable, hopeful or apprehensive comment. It will be almost impossible for you to realize such a condition of negativity and deadness. No one portion of the universe would then have importance beyond another; and the whole collection of its things and series of its events would 
Humanistic ethics came to emphasize human rights. ${ }^{6}$ Rights is a concept found neither in biology nor, for that matter much in the ethical past. Since the origin of morality, ethics has meant choosing right against wrong. Defining what is "right" is at the core of any ethics. Increasingly since the seventeenth century, however, philosophers have used the term "rights" to protect certain human values. A right - used as a noun - is a person's entitlement to have other persons treat her in certain ways. ${ }^{7}$ A right is a valid claim that a person can make, or have made on her behalf, to have her interests or welfare taken into account. Human rights are statements of basic needs or interests that are politically significant as grounds for protest, for legal treatment, and as justifications in reforming practices and policies. They invoke justice and equality, rather than benevolence or charity. They propose standards of individual treatment which every culture ought to recognize and protect. ${ }^{8}$ Human rights produce a legally justified constraint on how other

be without significance, character, expression, or perspective. Whatever value, interest, or meaning our respective worlds may appear endued with are thus pure gifts of the spectator's mind.

WIIIIAM JAMES, THE VARIETIES OF RELIGIOUS EXPERIENCE 150 (1925).

6. The other broad ethical tradition is utilitarianism, which focuses more on goods or utilities. These too are almost always human preferences to be satisfied.

7. A right is a person's justified entitlement to something from someone. Joel Feinberg, Duties, Rights, and Claims, 3 AM. PHIL. Q. 137 (1966). Rights can differ with the level of development of a nation. Some moral rights can be nation-specific and time-bound. Contemporary Americans have a moral right to levels of nutrition, shelter, welfare, and education that would not have been feasible earlier. One author has offered this representative, though incomplete, list of current international human rights:

1. The right to freedom of physical movement

2. The right to ownership of property

3. The right to freedom from torture

4. The right to a fair trial

5. The right to nondiscriminatory treatment

6. The right to physical security

7. The right to freedom of speech and association

8. The right to minimal education

9. The right to political participation

10. The right to subsistence

ThOMAS DONALDSON, THE ETHCS OF INTERNATIONAL BUSINESS 81 (1989).

8. For a concise introduction to the concept of rights see Stanley I. Benn, Rights, in 7 ENCYCLOPEDIA OF PHILOSOPHY 195 (1967) and the older bibliography printed therein. Other introductions include: DANIEL W. BROMLEY, ENVIRONMENT AND ECONOMY: PROPERTY RIGHTS AND PUBLIC POLICY (1991) (concentrating on property rights, natural resources, and environmental conservation); JAMES W. NICKEL, MAKING SENSE OF HUMAN RIGHTS: PHILOSOPHICAL REFLECTIONS ON THE UNIVERSAL DECLARATION OF HUMAN RIGHTS 13-35 (1987) (providing an extended definition of rights); Joel Feinberg, The Nature and Value of Rights, 4 J. VALUE INQUIRY 243 (1970); Feinberg, supra note 7; H.J. McCloskey, Rights-Some Conceptual Issues, 54 AUSTRALASIAN J. PHIL. 99 (1976). Other recent major works are: RoNALD DWORKIN, TAKING RIGHTS SERIOUSLY (1977); JOHN FINNIS, NATURAL LAW AND NATURAL RIOHTS (1980); MTCHAEL FREEDEN, RIGHTS (1991); HUMAN RIGHTS (Ellen F. Paul ed., 1986); HUMAN RIGHTS: Cultural and Ideological Perspectives (Adamantia Pollis \& Peter Schwab eds., 1979) (including narrative bibliography); A.J.M. MIINE, HUMAN RIGHTS AND HUMAN DIVERSITY (1986); THE PHILOSOPHY OF HUMAN RIGHTS: INTERNATIONAL PERSPECTIVES (Alan S. Rosenbaum ed., 1980); THEORIES OF RIGHTS (Jeremy Waldron ed., 1984); UNESCO, PHILOSOPHCAL FOUNDATIONS OF HUMAN RIGHTS (1986). 
persons may treat the person possessing the right. ${ }^{9}$

Rights can vary in kind: some are inalienable, at the core of human wellbeing; some can be bought and sold; some can be forfeited by wrong behavior; some cannot. Some are legal rights: privileges and possessions that persons have by virtue of their citizenship; when denied, these rights can be claimed by due process of law. Some are moral rights: claims made about goods universal to human persons, regardless of their citizenship. A citizen has a legal right to vote. Innocent persons have a moral right not to be killed, regardless of whether they have an equivalent legal right. In an ideal world, legal rights would mirror moral rights.

In contrast to legal rights, moral rights are sometimes called "natural" rights, not because they can be discovered by studying nature from a scientific point of view but because they arise from human nature. Whatever roots humanity has in the animal world, whatever biology we continue to have in common with animals, characteristics have emerged that were not present before humans evolved and are not now present in the non-human world. Humans have opportunities and confront basic choices involving language, deliberation, rationality, reflective self-consciousness, responsible community membership and so forth that the non-human world does not have or confront. Moreover, human life is by nature political. Since political processes can interfere with personal well-being, political animals must be protected by rights. Rights protect core goods, those intrinsic to personality and those most likely to be politically threatened. Rights do not derive from legislative or judicial action; they are intrinsic to the nature of personhood. The Neanderthals had "rights" if their society had values which other Neanderthals could not destroy without overriding justification.

Rights protect certain human goods, "virtues"10 thought especially important. Some of these goods are created by our culture, others by nature. Rights issues arise when such goods need to be protected against the incursions of other humans. All resolutions of rights issues occur in the cultural environment of humans interrelating with other humans. "Man is by

9. Conceptualized in this way, rights are a Western construct. Ancient, preliterate, and Eastern cultures do not typically speak of rights as such; instead, they describe various human goods, excellences, or liberties. The Bible, Plato, and Socrates say nothing about rights, although each evaluates right and wrong behaviors. Though originally a Western model, human rights have been widely asserted around the globe. Nevertheless, defenders of rights must ask whether rights are sufficiently compatible with the value systems of the diverse world cultures to serve as the dominant model for a global human ethics, or an Earth ethics. See generally Adamantia Pollis \& Peter Schwab, Human Rights: A Western Construct with Limited Applicability, in HUMAN RIGHTS, supra note 13; ASIAN PERSPECTIVES ON HUMAN RIGHTS (Claude E. Welch, Jr. \& Virginia A. Leary eds., 1990).

10. A recent movement in ethics that swings back to a more classical category is virtue ethics, which focuses on certain human excellences that are cultivated within a cultural tradition. This movement returns to the vocabulary of Aristotle. See, e.g., ALASDAIR MCINTYRE, AFTER VIRTUE (2d ed. 1984). 
nature a political animal," said Aristotle ${ }^{11}$ - the animal who builds and inhabits a "polis," a city. The human kind is genetically an animal, but specifically a citizen; that is the differentia that identifies the human essence. ${ }^{12}$ Hence we expect that an ethics will arise to govern conduct in the "polis," channelling and orienting behavior to protect the goods of human nature and culture. When we turn to spontaneous nature, that is nature which is not affected by human intervention or deliberation, what then? Things change - dramatically.

\section{B. Rights and Nature}

That the concept of rights that has worked so well to protect human dignity is a hallmark of recent cultural progress. The rights model, however, proves troublesome when used to protect the biological world. ${ }^{13}$ We thus face a paradigm crisis in ethics that is produced by the ecological crisis in our environment. Nature knows no rights. There were no rights over the millennia of evolutionary time - nor are there today, outside the human sector. Trees, grasses, and wildflowers do not have rights, nor can they recognize the rights of others. They do not have responsibilities. They do not assert claims and entitlements against each other. The mountain lion does not violate the rights of the deer he slays. Even the lion who eats a human does not violate that human's rights. The lion is not guilty of reprehensible behavior for which he can be shamed or brought into court. The mountain lion can establish no relationships outside wild nature. The human, however, does have a right to be rescued from danger by other humans because of his relationships to other humans. If, for instance, national park service officials made no effort to rescue a human from a cougar attack and only stood by and watched, they would be morally as well as legally responsible. Rights go with legitimate claims and entitlements, but there are no entitlements or laws that can be transgressed in the wilderness. Rights go with appeals to moral agents who ought to protect certain human goods. Nature is amoral, though perhaps valuable.

Using the language of rights for rocks, rivers, plants, and animals is comical, because the concept of rights is an inappropriate category for nature. John Muir once lamented, "How narrow we selfish, conceited creatures are in our sympathies! How blind to the rights of all the rest of the creation!"14

11. ARISTOTLE, THE POLITICS I, 2 (1253').

12. Id.

13. For positive defenses of the rights of natural things, see RODERICK FRAZIER NASH, THE RIGHTS OF NATURE: A HISTORY OF ENVIRONMENTAL ETHICs (1989); Stephen R.L. Clark, The Rights of Wild Things, 22 INQUTRY 171 (1979); Mary Anne Warten, The Rights of the Nonhuman World 109, in ENVIRONMENTAL PHILOSOPHY (Robert Elliot \& Arran Gare eds., 1983).

14. JOHN MUR, A THOUSAND-MLE WALK TO THE GULF 98 (1916). 
We can appreciate the rhetoric, the poetry, and the lament, but can we take seriously the rights of the alligators, the rushes, the lilies, the ferns, and the swamps to which Muir was referring?

Aldo Leopold, who launched the idea of a land ethic, did say more soberly: "The land ethic simply enlarges the boundaries of the community to include soils, waters, plants, and animals, or collectively, the land. . . . A land ethic of course cannot prevent the alteration, management, and use of these 'resources,' but it does affirm their right to continued existence, and, at least in spots, their continued existence in a natural state." The land "should continue as a matter of biotic right. "15 Leopold pleads for appropriate human behavior; thus he expands rights to include the biotic environment. Like Muir, Leopold tries to claim that biological existence confronts humans with a value and that it is not right for humans to destroy this value arbitrarily. Although the reader may want to make a similar claim, it is necessary to face the fact that there are no rights in the relationship between one part of nature and another part.

\section{Animal Rights?}

Some have argued that rights, though absent in wild nature, are generated when humans confront biotic nature. According to Charles S. Elton, an ecologist, "[t]here are some millions of people in the world who think that animals have a right to exist and be left alone." 16 Philosopher Arne Naess says of animals that "in principle each of them [has] the same right to live and blossom as we and our children have. " ${ }^{17}$ A sign in Rocky Mountain National Park urges visitors not to harass the bighorn sheep: "Respect their right to life." Tom Regan argues at great length for animal rights. ${ }^{18}$

However, the concept of animal rights is problematic. We may speak with some plausibility of the rights of chimpanzees and dolphins, our nearby relatives in nature who almost seem to have personalities. However, it is more difficult to speak of the rights of birds or of bats despite the fact that bats are mammals too, and it is troubling to speak of any rights at all of oysters and insects. Moving across the spectrum of animals, the concept of rights translates from human affairs to human-animal relations less and less easily. Rights readily attach to values we wish to protect in persons. Because the proposed objects of moral concern, wild animals, have nonpersonal values, much of what we wish to protect in humans does not exist in animal nature. ${ }^{19}$

15. ALDO LEOPOLD, A SAND COUNTY ALMANAC 219 (1966).

16. Charles S. Elton, The Ecology of INYasions by ANImals and Plants 143 (1958).

17. Arne Naess, $A$ Defence of the Deep Ecology Movement, 6 ENVTL. ETHICs 265, 266 (1984).

18. TOM REgAN, THE CASE FOR ANIMAL RIGHTS (1983).

19. For denials that animals have rights, see R. G. FREY, INTERESTS AND RIGHTS: THE CASE 
Regan claims that we should not arbitrarily restrict rights to persons. ${ }^{20}$ Still, animal rights are not natural in the sense that they exist in spontaneous nature. By constructing the concept of rights, Western ethicists discovered a way to protect values present in persons. If there are animal rights, they seem to exist only when persons come on the scene; animal rights do not exist in the absence of persons. Perhaps rights are generated by the encounter of moral agents with sentient life. If so, rights, clearly present in or assigned to persons, should also be found or assigned to nonhumans when persons encounter higher sentient animals. Such rights would not be natural in the sense that they exist in wild nature; they would be cultural products, brought by persons who extend rights from culture to nature. Such rights would emerge only when humans intervene in ecosystems. Humans must sometimes affect sentient life adversely. We may sometimes affect it beneficially. When we do either, we might say that some animals gain a right, otherwise unknown in nature, to flourish in their own way. This right would protect animals from human intervention, and would correlate with a sense of intrusion on experience, which is present in higher sentient animals but vanishes lower down.

To say that $x$ has rights seems like a statement of fact. But it is really a valuation, embedding a prescription, claiming to have located something of value in the alleged possessor of rights. There are no rights present in the wild before humans arrive. Animals do have interests, desires, and needs. Certain things are important to them, vital to them, apart from the human presence. These things are valuable to them; they have, as biologists phrase it, survival value. Those animal values are not significant only for animals. We humans can and ought sometimes consider such values in deciding how we behave. Reconsider the sign that bids Rocky Mountain Park visitors not to harass bighorn sheep, and to "[r]espect their right to life." An ethical visitor directly respects their life, an objective fact in the wild, which is valuable to the animal and positively evaluated by the human who encounters such life. The italicized words can be subtracted without loss of logic or fact. These words can be pedagogically effective, but are not theoretically important.

It is really more accurate to say that animals have goods or, more technically, utilities. Goods do exist in wild nature, while rights do not. The goods of sentient animals are best examined by the concepts of health, interests satisfied, or welfare. Thus, what ethicists should really develop is a vocabulary of value. Animals enjoy values intrinsic to themselves, and appropriate respect for those values generates an ethics. "Rights" is a noun

Against ANIMALs (1980); Tibor R. Machan, Do Animals Have Rights?, 5 PUB. AFF. Q. 163 (1991).

20. REGAN, supra note 18 , at $185-93$. 
and can look like the name for something that an animal or a human has, in addition to hair, teeth, and skills. However, rights does not refer to anything biologically present. A right is more like a person's having "money" or "status." These things are intersubjectively, sociologically real and protect values that are inseparably entwined with personality. We might try to expand the concept of such rights and project them out of culture onto wild nature. This does not work convincingly, however, if we move far from analogical contexts. The concept breaks down because nature is not culture.

By contrast, "right" is an adjective; used to denote forms of behavior engaged in by moral agents. The concept of "rights" merely states claims about "right" behavior. Ethics uses rights as a term of convenience; the real underlying convictions are about what is right. Ethical issues always revert to evaluations of right behavior.

In references to nature, it is therefore better to dispense with the term rights, since rights do not attach to animals in the wild. The word right is a more fitting term, because it refers to behavioral obligations arising when moral agents encounter and find something valuable in nature. Ethics arises only when the moral agent arrives, but the value exists apart from human involvement. Although sometimes convenient rhetorically, in principle the concept of rights is unnecessary to the development of an ethic which respects values found in nature.

In short, rights is a political concept which attaches to the human animal that lives in a polis, but is not well suited to nonpolitical animals. Rights protect life in cultures in which persons desire liberty for the pursuit of happiness in their nation states. The language of rights has proved among the most powerful of the political and ethical concepts of recent centuries. It is an effective tool in protecting personal dignity. Unfortunately, the paradigm that works so well in the context of culture cannot be extrapolated successfully to nature.

\section{Human Rights to Nature}

However, another application of the rights concept is valid and becoming increasingly vital in environmental ethics. Perhaps we cannot directly extrapolate rights into nature or into our human dealings with animals and plants, but we can apply human rights to human needs for environmental integrity. The ecological movement has made it clear that culture remains tethered to the biosystem and that the choices provided by our built environments, however numerous, do not release us from nature. Humans depend on air flow, water cycles, sunshine, photosynthesis, nitrogen-fixation, decomposition bacteria, fungi, the ozone layer, food chains, insect pollination, soils, earthworms, climates, oceans, and genetic materials. Ecology always lies in 
the background of culture. Some sort of inclusive environmental fitness is required of even the most advanced culture. Regardless of how we rebuild our environment, humans remain residents of an ecosystem.

Earlier ethics and law did not pay much attention to ecosystems because humans had little scientific knowledge of ecological processes and even less power to affect these processes. Lately, however, increases in human population and advances in technology have enabled us to modify drastically our life support system. These alterations threaten persons, and therefore raise ethical questions. Humans now need to assert a right to a decent environment. If there is any such thing as natural rights, privileges that we possess just by being born on Earth, the right to nature is foremost among them. In this sense, natural rights will not refer, as before, to values intrinsic to the nature of personhood, but to instrumental natural givens, intrinsic to human ecology, to which humans have a birthright. Other humans have no right to dispossess persons from this natural heritage. ${ }^{21}$

Such a right to the natural environment includes protection of air, soils, waters, essential biological processes, the sustainable productivity of the land, preservation of biodiversity, protection against contamination by toxic substances, access to natural resources essential for life, and perhaps access to public lands and commons. Claiming such a right will be an assertion about nature, not culture, but it will not be an assertion directed to nature, the source of these goods. Rather, the claim of environmental rights will be directed to other humans. Such a claim, will regulate the affairs of culture, as these affairs now touch upon the life support system. It will be a political claim. Environmental rights are emerging now because our life support system is threatened. ${ }^{22}$

Cultures intertwine with their landscapes, and the goods of culture often require the conservation of natural goods in order to support and enrich life. No culture develops independently of the environment on which it is superimposed. Distinctive landscape features always underlie culture. The Finger Lakes are part of the ethos of central New York state. Shorelines are essential to the culture of Prince Edward Island. The British have their moors, the Germans their Black Forest, and the Russians their steppes. However

21. A partial exception lies in the right to own property. Widely recognized, see supra note 7, this right consists in the right to occupy and develop parcels of land with surveyed boundaries. Property rights are not absolute: they are constrained by the need to protect other property holders and the public good in general. See generally BRUCE A. ACKERMAN, PRIVATE PROPERTY AND THE CONSTITUTION (1977); Ellen Frankel PaUl, Property Rights aNd EMINENT DomaIn (1987); Joseph L. Sax, Takings, Private Property and Public Rights, 81 YALE L.J. 149 (1971). Previously, however, we did not have to establish rights to the landscape in the ecological sense.

22. Pope John Paul II insists, "The right to a safe environment . . . must be included in an updated charter of human rights." Pope John Paul II, Peace with All Creation, 19 ORIaINs 465, 467 (1989); see also Alexander S. Timoshenko, Intemational Environmental Law and the Concept of Ecological Security, BREAKTHROUGH, Summer-Fall, 1989, at 22-24. 
much the native wildness is domesticated, humans want some nature preserved, for it expresses the values of the culture superimposed on it. Consider, for example, the psychological connections between the Mississippi River and the state of Mississippi. Consider also the connections between the Scots and Loch Lomond. What would Florida be without its flora? The use of nature to symbolize culture has been a repeated feature in the myriad cultures on Earth. The bald eagle symbolizes American self-images and aspirations such as freedom, strength, and beauty, as does the bighorn ram, the state animal of Colorado. The pasqueflower is a symbol for South Dakota, the alligator a symbol for Florida, the moose for Maine, the maple leaf for Canada, the trillium for Ontario, and the arbutus for Nova Scotia.

The only way a state can effectively convey a right to a natural environment is by protecting nature from degradation by humans. The state can protect, permit, conserve, and constrain human interactions with nature. In this respect the right to nature parallels the right to life, for the state does not convey life either; it only safeguards this natural given. The right to life is unlike the right to vote, to trial by jury, to hold legal property, to national defense, or to a minimum wage. The Colorado River, along which many have water rights, both does and does not flow by act of Congress. Congress cannot make the river flow; but without Congressional legislation the river would have long since dried up from overexploitation. Government can only act so as to permit the continued flow of natural goods. The right to water is a political right that preserves something provided by nature.

This most recent use of the rights paradigm is an important one. We have discovered that there is one more domain of value, always present but only lately consciously appreciated, that is now so threatened that it must come under political protection. Perhaps we will need to amend the U.S. Constitution to include a right to an environment with integrity. ${ }^{23}$ States might add such a right to the Universal Declaration of Human Rights or issue a separate declaration on the right to environmental integrity. ${ }^{24}$ Nations currently

23. The National Wildife Federation has proposed an Environmental Quality Amendment to the U.S. Constitution. Amending the Constitution probably is politically infeasible, but the idea is logically sound.

24. The present text of the Universal Declaration of Human Rights contains nothing on the natural environment. G.A. Res. 217, U.N. Doc. A/811 (1948). The 1972 U.N. Conference on the Human Environment in Stockholm sought to delineate the rights of the human family to a healthy and productive environment. See EDMUND J. OSMANCZYNC, THE ENCYCLOPEDIA OF THE UNITED NATIONS AND INTERNATIONAL RELATIONS 874-876 (1990). The World Commission on Environment and Development has proposed: "[A]ll human beings have the fundamental right to an environment adequate for their health and well-being." WORLD COMM'N ON ENV'T AND DEVELOPMENT, ENVIRONMENTAL PROTECTION AND SUSTAINABLE DEVELOPMENT: LEGAL PRINCIPLES AND RECOMMENDATIONS 9 (1987). See also WORLD COMM'N ON ENV'T AND DEVELOPMENT, OUR COMMON FUTURE 348-51 (1987) (Summary of Proposed Legal Principles for Environmental Protection and Sustainable Development Adopted by the WCED Experts Group on Environmental Law). The U.N. Commission on Human Rights, through its Sub-Commission on Prevention of Discrimination and Protection of Minorities, is currently studying the application of human rights to environmental problems; their final report is scheduled to be issued in August 1993. 
revising their constitutions should include the right to nature as a constitutional right. Therefore, we should affirm, among other human rights, a right to a quality environment. ${ }^{25}$

However, we should also recognize that this analysis seeks to protect the Earth by adding on to the paradigm of rights theory, rather than facing up to the larger epistemic crisis. It adjusts that periphery of the old theory, rather than looking for a new one. This can seem the prudent approach, because ethicists have fought long and hard to convince the world's societies to acknowledge human rights. It might be thought that introducing a new paradigm will confuse these efforts and stall progress. But, later on, in addition to affirming a quality environment for humanity, we will need to go beyond our rights, to human responsibilities for nature.

What is a quality environment? It is readily clear that humans have a right to an environment that is healthy. Humans are helped or hurt by the condition of their environment. If humans have a right to life, liberty, and the pursuit of happiness, then they have a right to the natural conditions that are necessary to produce these ends. This includes the basics, such as air, soil, water, functioning ecosystems, and hydrologic cycles. It also includes environmental amenities such as wildlife and wildflowers, scenic views, and access to natural areas, because these amenities are also essential to wellbeing.

In sum, such a "right to nature" is a right within culture. That is, it is a claim we can make against other humans who jeopardize a healthy environment. Aggregating these claims at the global level, it is possible to say that humans have a right to this home planet. That would not mean that humans have some kind of claim against Mother Nature. As noted previously, nature is not a moral agent. We cannot lay claims against nature, any more than we can lay claims against grizzly bears or wildflowers, rivers or mountains. At the same time, the Earth and its ecosystems are valuable not simply because we value them, but because they are able to produce all the values achieved in natural history. Nature is prolific, but not responsible.

\section{RESPONSIBILITIES: RESIDENTS ON A VALUABLE EARTH}

Humans have a responsibility to protect what we have been given on the Earth. At the most fundamental biological level we must protect life - not

25. The terminology that would define such a right is still open to debate. Possibilities include the right to a natural environment with quality, health, and integrity, to a productive environment, to an environment adequate for well-being, or to a sustainable environment without permanent degradation of resources. The right might be timebound and nation-specific; the detail of application could vary with the degree of environmental alteration that has already taken place or with the relative richness of natural resources on differing landscapes. See William Aiken, Human Rights in an Ecological Era, 1 ENVTL. VALUES 191 (1992). 
simply our own human lives, the domain of ethics and law hitherto, the domain that a human right to a quality environment might protect, but the larger community of life, to which ethics and law now must be extended. The rights paradigm must be left behind in favor of a concept based on what is right: this is the planet that is right for life and it is right that life continue here.

The usual correlative of rights is responsibilities. Rights protect our deepest human values, but having rights means having responsibilities. We are answerable for the values that we ourselves may threaten. If I have the moral right to life, liberty, and the pursuit of happiness, by a complementary logic I have a moral responsibility to value these ends in other humans. Whatever we have a right to, we also have a responsibility for. Conversely, our responsibilities can delineate our rights; if we do not have a responsibility to act or to refrain from acting in a certain way, we do not have a right to expect such behavior from others.

Responsibilities adhere to humans when we encounter the nonhuman world as well, despite the fact that the objects of moral concern are not themselves moral agents. A responsibility in this context is a duty that arises when we gain the power to threaten existing or potential value in the world. Responsibilities of the moral kind are found only in Homo sapiens because humans are the only beings with inherent moral capacity. Plants and animals do not have such responsibilities, much less do rivers and mountains.

Given that humans have responsibilities to the natural world we must ask what values are found in the natural world. Identifying such values will generate specific duties in persons of conscience. Certainly such persons must use nature's values as resources for producing values in cultural and personal life. In doing so, however, they recognize that exploiting values found in the world only for their own self-interest is not responsible.

The right to our natural heritage comes with a responsibility for our natural heritage. Humans have responsibilities when encountering values in nature; we should respect value wherever it is found, including value found at levels of being that are not human and are therefore incapable of carrying either rights or responsibilities. Such beings do carry life, and life is not worthless merely because it is neither human nor exploitable by humans.

\section{A. Responsibilities to and for Life}

Part II.C concluded that wild animals do not have rights, but they do have value; as such, there are animal goods that we should protect. Extending the analysis from fauna to flora, this part will consider the larger domain of biological values, and of our responsibilities to them. Plants do not have 
rights, but are there values present in them? ${ }^{26}$ If so, responsibilities arise to protect these values.

Initially, the idea that plants have intrinsic values can seem strange. A plant is not a valuer with preferences that can be satisfied or frustrated. It seems odd to claim that plants need our sympathy, odd to ask that we consider their point of view. They have no subjective life, only objective life. Value, however, may not always be a matter of subjective preferences satisfied or of felt experiences. Though nothing matters to a tree, much is vital to it. Like animal organisms, a floral organism is a spontaneous, self-maintaining system which sustains and reproduces itself. Plants are modular organisms, with a meristem that can repeatedly and indefinitely produce new vegetative modules and new reproductive modules that contain the DNA coding to organize more of their kind. Botanical organisms possess historical information systems with genetic coding that enables them to make a way through the world. In this sense, the genome is a set of conservation molecules. Given a chance, these molecules seek organic self-expression. Genomes enable plants, unlike inert rocks, to claim the environment as source and sink, from which to extract energy and materials and into which to excrete them. An acorn becomes an oak; the oak stands on its own.

The description thus far is purely botanical even when it describes what is vital to plants. Philosophical value arises by recognizing that the genetic set is a normative set: it distinguishes between what is and what ought to be. This does not mean that a plant is a moral system or a conscious valuer, but that a plant is nevertheless an evaluative system. The oak grows, reproduces, repairs its wounds and resists death. The physical state that the organism seeks, idealized in its programmatic form, is a valued state. Value is present in this achievement. Vital better describes these metabolic processes than biological; vital is a crossover word that ties descriptive biology to evaluative biology. A life is defended as an end in and of itself. Every organism has a good-of-its-kind; it defends its own kind as good kind.

When humans encounter such living organisms, we find ourselves in the presence of something vital, something pursuing its own values. In light of such values, we become responsible four our behavior. Moral agents take account of the consequences of their actions for other evaluative systems. We have a responsibility to protect values that are jeopardized by our behavior. We will, of course, have to balance the human values that we pursue against the biological values that we encounter. In doing so, we will judge values, and will thereby encounter the essence of moral decision making.

26. For further discussion of this question, see RoLsTON, ENVIRONMENTAL ETHICs, supra note 5, at 94-125; Robin Attfield, The Good of Trees, 15 J. VALUE INQUIRY 35 (1981); Holmes Rolston, III, On Behalf of Bioexuberance, GARDEN, July-Aug. 1987, at 2. 


\section{B. Responsibilities to and for Species}

Human responsibilities to nature increase at the species level. ${ }^{27}$ Species are specific forms of life historically maintained in their environments over time. The individual represents a species in each new generation. The individual is a token of a type, and the type is more important than the token. A species lacks moral agency, reflective self-awareness, sentience, or organic individuality. A species has no self, but it has a biological identity reasserted genetically over time. The life that the individual has is something passing through the individual as much as something it intrinsically possesses. A true respect for life thus requires us to attach duty to the broader form of life just as much as to the individual representation. Indeed, it is more important to protect species vitality than to protect individual integrity. Extinction is an irreversible harm brought about by human action or carelessness. Never before has one form of life endangered so many others. Never before has superkilling by a superkiller been deliberately faced. Humans have more understanding than ever of the natural world they inhabit and of the speciating processes. They have more predictive power to foresee the intended and unintended results of their actions and more power to reverse the undesirable consequences. The responsibilities that such power and vision generate are not simply to individuals; instead, they are duties to specific forms of life. What is now required is principled responsibility to the biospheric Earth. ${ }^{28}$

If, in this world of uncertain moral convictions, it makes any sense to claim that one ought not to kill individuals without justification, then it makes even more sense to claim that one ought not to kill species without superjustification. Several billion years worth of creative toil, several million species of teeming life, have been handed over to the care of our late-coming species in which mind has flowered and morals have emerged. Life on Earth is a many-splendored thing. Extinction dims its lustre.

\section{Responsibilities to and for Ecosystems}

Ecosystems are unfamiliar moral and legal territory. It is difficult to understand the biology of ecosystems; therefore it is even more difficult to formulate ethical and legal systems that account for ecosystemic values. Fortunately, it is evident that human welfare depends on ecosystemic support;

27. See JOHNSON, supra note 2, at 162-75; ROLSTON, ENVIRONMENTAL ETHICs, supra note 1, at 12659; Holmes Rolston, III, Duties to Endangered Species, 35 BIOSCIENCE 718, 722-23 (1985); Holmes Rolston, III, Property Rights and Endangered Species, 61 U. CoLo. L. REV. 283, 303-04(1990).

28. The principal U.S. legislation protecting species is the Endangered Species Act of 1973, Pub. L. No. 93-205, 87 Stat. 884 (codified as amended in scattered sections of 16 U.S.C. \& 7 U.S.C. $\$ 136$ (1982 \& Supp. 1984)). The principal convention is the Convention on International Trade in Endangered Species of Wild Fauna and Flora, Mar. 13, 1973, 27 U.S.T. 1087. 
in this sense, all our legislation about clean air, clean water, soil conservation, national and state forest policy, pollution controls, and renewable resources addresses ecosystemic processes. ${ }^{29}$ Further, humans find much of value in preserving wild ecosystems, such as our wilderness and park systems and our biological reserves. We can do a great deal by preserving ecosystems for the sake of human welfare. Still, a comprehensive environmental ethic needs naturalistic reasons, as well as humanistic ones, for respecting ecosystems. Aldo Leopold urged extending ethics to the land as a community because he was concerned about the welfare of nonhumans as well as that of humans, and he was concerned about this welfare at the level of community integrity. ${ }^{30}$ This concern was well placed.

What exactly is an ecosystem? Can an ecosystem be a community of value? Biologists describe ecosystems as objectively interdependent communities where organismic needs are sufficiently satisfied for species to survive over the long term. Each individual animal or plant defends its own particular life, but nothing can survive on its own; everything lives in relationships to other things. The ecosystem outside the organism is as vital as the biochemistry within. Therefore, to defend life, humanity must defend the whole context of life. A moral agent ought to find that ecosystems are satisfactory communities to which to attach duty.

Like plants and species, however, ecosystems are not traditional objects of duty, much less holders of rights. Unlike higher animals, ecosystems have no experiences; they do not and cannot care. Unlike plants, ecosystems have no genomes. Unlike species, ecosystems do not have an ongoing organismic identity, reinstated over time. Ecosystems can seem like jungles where the fittest survive, places of contest and conflict, or of haphazard juxtaposition. Nevertheless, more fundamentally, ecosystems are productive, vital systems, which support and limit each kind. Species increase their kind, but ecosystems increase their kinds and generate ever-richer communities. This function epitomizes the evolutionary toil, the process which elaborates and diversifies the biota that once began with zero species and today has over five million species - from protozoans to primates to people.

Ethical humanists argue that ecosystems are of value only because they contribute to human experiences. ${ }^{31}$ That approach, however, mistakes the last

29. There is no Endangered Ecosystems Act. However, designation of an area as wilderness under the Wilderness Act of 1964, Pub. L. No. 88-577, 78 Stat. 891, effectively subjects the ecosystems within it to supervision. All of the important congressional forestry and grasslands legislation in recent decades has contained language about resource sustainability, which typically requires ecosystem-oriented management. See, e.g., Federal Land Policy and Management Act of 1976, Pub. L. No. 94-579, 90 Stat. 2743; National Forest Management Act of 1976, Pub. L. No. 94-588, 90 Stat. 2949. The current "New Perspectives in Forestry" emphasis in the U.S. Forest Service is quite ecosystem-oriented.

30. See LEOPOLD, supra note 15 , at $x$ (stating that "when we see land as a community to which we belong, we may begin to use it with love and respect. . . . That land is a community is the basic concept of ecology, but that land is to be loved and respected is an extension of ethics.").

31. See, e.g., William F. BaXter, People or Penguins: The Case for Optimal pollution 5 
chapter for the whole story, one fruit for the whole plant. Humans count enough to have the right to flourish here, but not so much that they have the right to degrade or shut down ecosystems, at least not without demonstrating an overriding cultural gain. Fundamentally, the stability, integrity, and beauty of biotic communities must be conserved. We must concern ourselves with the fundamental unit of survival. This unit is not individuals or species, but ecosystems - the dynamic communities which persist and evolve over time.

\section{Responsibilities to and for Earth}

Environmental ethics is not complete until it is an Earth ethics which considers human responsibilities at the global level. People on a landscape may speak about "the land." Leopold's vision was of a land ethic. In our shrinking world, however, the land, the good earth, is really the whole planet, the good Earth. In an ethic of respect for life, the appropriate level of moral concern is the appropriate survival unit. The planet is the ultimate survival unit. No longer does it seem that humans count alone, with everything tributary to them; humans count as residents on this majestic planet.

Earth ethics reinforces the argument that "value" language is more comprehensive than "rights" language. For even if things like animals, plants, species, ecosystems, or planets cannot have rights, we can still have responsibilities toward them because they have value. Humans have dominion over the Earth only in the sense that Adam and Eve were granted dominion - a stewardship or trusteeship over something entrusted into their care. Though foreshadowed by the sense of belonging that many peoples have had on their landscapes, loyalty to the planet is the newest demand in ethics. It is a new possibility that could also prove to be the highest level of duty.

\section{Political Citizens and Fragmented Responsibitity}

Superimposed on fauna, flora, ecosystems, and indeed on the planet itself, is the politically fragmented world of human culture. There is one Earth, but on it are one hundred and seventy eight sovereign nations. The Brundtland Report begins, "[t]he Earth is one but the world is not." ${ }^{132}$ True, the one Earth supports myriads of ecosystems, diverse species, and diverse peoples. Still, divisive troubles arise among the nation-states. A system of national sovereignties is not well adapted for harmonious relations with the Earth commons. ${ }^{33}$ The rights of nations, and rights as claimed by citizens of these

(1974); Bryan G. Norton, Environmental Ethics and Weak Anthropocentrism, 6 ENVTL. ETHCs 131, 133 (1984).

32. OUR COMMON FUTURE, supta note 24, at 27.

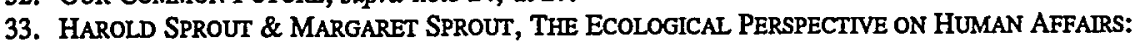


political states, are not well aligned with the well-being of the planet. During this century, the commons problem has become transnational at regional levels. At the turn of the millennium, it is becoming critical at global levels. Unfortunately, our citizenship is not synchronized with our residency.

\section{A. Nation States and Natural Resources}

Many of Earth's natural resources, unevenly and inequitably distributed, must flow across national boundaries if there is to be a stable community of nations. People have a right to water. That right seems plausible and just, because water is essential for life. However, the relationship between the hydrology of the planet and national boundaries often interferes with this right. At least 214 river basins are multinational. More than $75 \%$ of the total area of about 50 countries falls within international river basins. An estimated $35-40 \%$ of the global population lives in multinational river basins. In Africa and Europe most river basins are multinational..$^{34}$

With escalating population and pollution levels, sharing water ${ }^{35}$ has become increasingly an international issue. It is no longer a simple matter of looking upstream and downstream. Water moves around the globe on air currents, so that there is meteorological water as well as hydrological water. The flow of water is a cultural resource that, however much modified by pipe lines and pumps, remains inseparably part of natural meteorological and hydrological systems. For example, shared meteorological water can transmit one country's pollutants to another in the form of acid rain.

Water itself has no rights, but water is the wellspring of life. There are no rights to water in wild nature, but all fauna and flora depend on it. Water is the principal resource that makes Earth right for life. The existence of humans gives rise to water rights. However, human political culture alone should not dictate how water rights are exercised. Water rights ought not to be exercised in politically fragmented jurisdictions, unintelligently related to the hydrology of the landscape. We may buy and sell water rights, but we must also use water in responsible harmony with natural systems. In using water, we must be residents of Earth, not just citizens of nations.

This reasoning applies to other essential resources as well. The shapes of

WITH SPECIAL REFERENCE TO INTERNATIONAL POLITICS 5-18 (1965). This part deals with national states. Multinational business organizations are another concern, often undermining national efforts to be environmentally responsible. Like the sovereign nations, they, too, operate in their own interests and are not adequately regulated by any one government. By shifting from nation to nation, multinational busincss entities engender deregulatory competition among nation states. Although multinational corporations could enforce international environmental standards, they often fragment them.

34. GLOBAL RESOURCES AND INTERNATIONAL CONFLICT: ENVIRONMENTAL FACTORS IN STRATEOIC POLICY AND ACTION 97 (Arthur H. Westing ed., 1986) [hereinafter GLOBAL RESOURCES].

35. Note that the word rival comes from the Latin word for river, rivus, and refers to those who share flowing waters. 
the continents are clearly the result of natural forces, which deposit natural resources without concern for political boundaries. Similarly, leaders draw national boundaries primarily for political reasons and often with minimal attention to natural resources. Nearly all national boundaries were drawn before many essential resources, such as coal, electric power, uranium, copper, or iron ore, were considered resources at all. For example, petroleum on Earth is highly concentrated. One quarter of the known reserves are in Saudi Arabia, and more than half are in the Middle East. ${ }^{36}$ However, the need for petroleum is global. We might say that people have a right to petroleum because it is difficult nowadays to be either productive or free without it. Nevertheless, most national boundaries are only accidentally related to the location of this most valuable natural resource; $;^{37}$ therefore these boundaries tend to misallocate the resource.

It is not enough to claim a right to petroleum. We have a responsibility to determine how to use this non-renewable global resource in a way that will increase stability between nations and their landscapes, and diminish our current vulnerability to political affairs. The United States recently spent enormous amounts of money and energy and sacrificed human lives to defend lands containing petroleum. One reason for the war was to protect the rights of a people who were victims of aggression; another was to protect access to petroleum for the community of nations. In order to protect this access, the United States had to protect a political entity whose boundaries are not drawn with any particular reference to the ecology of the region. These boundaries exacerbate the fundamental problem: in the Middle East, as elsewhere, political rivalries do little to distribute valuable resources equitably, nor do they encourage countries to give sufficient attention to a long-term, renewable energy plan.

Furthermore, those who fought the war inflicted great damage to the fauna and flora and to the fragile ecosystems over which their war machines raged. Iraq made massive, deliberate oil spills as a tactical measure. Most mammals in the Persian Gulf - including several species of whales, bottle-nosed dolphins, and the dugong, an animal similar to Florida's manatees - were drenched with oil. Thousands of species of marine life - birds, shrimp,

36. GLOBAL RESOURCES, supra note 34, at 11-12.

37. The Stockholm International Peace Research Institute (SIPRI), together with the U.N. Environment Programme, produced an excellent series of studies, listing hundreds of authorities, that analyze the international political pressures that arise over natural resource distribution and that often result in wars, violence, and environmental degradation. These studies also formulate ethical, legal, and political recommendations to alleviate these pressures. See generally CULTURAL NORMS, WAR AND THE ENVIRONMENT (Arthur H. Westing ed., 1988); ENVIRONMENTAL WARFARE: A TECHNICAL, LEGAL AND POLICY APPRAISAL (Arthur H. Westing ed., 1984); EXPLOSIVE REMNANTS OF WAR: MTTIGATING THE ENVIRONMENTAL EFFECTS (Arthur H. Westing ed., 1985); GLOBAL RESOURCES, supra note 34; HERBICDES IN WAR: THE LONG-TERM ECOLOGICAL AND HUMAN CONSEQUENCES (Arthur H. Westing ed., 1984). 
crabs, fish, and sea turtles - were adversely affected. The population of Basra babblers, a bird endemic to the Gulf, was imperiled. The tiny island of Karan, the breeding ground for $80 \%$ of the region's green sea turtles, which were already an endangered species in the Gulf, was directly in the oil spill. The Gulf is essentially a closed body of water and will not recover from this pollution for quite some time. ${ }^{38}$ The result of the war was thus twofold. Access to oil and the right to be free from aggression were protected; however, every other aspect of the Gulf War made for irresponsible residence on the home planet. ${ }^{39}$

In an Earth ethics that protects a shared commons, the international fabric will have to be stable and dynamic enough so that a nation which is not selfsufficient can meet its needs by participating in international commerce. Nations must be able to repair their own resource deficiencies through international trade. Unless such commerce can be arranged, the environment will suffer and human rights to a decent environment and to a fair share of the world's resources and goods will be denied.

A tremendous number of people are undernourished. If people have rights to life, liberty, and the pursuit of happiness, then we must have a right to adequate food. Yet starvation persists despite the fact that food is available in the world to feed the hungry. However, for political or economic reasons such food does not flow to those who are hungry. As a result of these social barriers to resource distribution, the environment will be further degraded by starving peoples, and the downward spiral will continue.

\section{B. International Responsibility and Global Ethics}

The Earth has no single government. It will not have one in the foreseeable future. Since sovereign nations are unlikely to cede sovereignty to a world government, commons issues will continue to be negotiated in a

38. Lois Ember, War Devastates Ecology of Persian Gulf Region, CHEMICAL \& ENGINEERING NEWS, Mar. 11, 1991, at 5; Michael D. Lemonick, Dead Sea in the Making: A Fragile Ecosystem Brimming with Life Is Headed for Destruction, TIME, Feb. 11, 1991, at 40; Fred Pearce, Wildlife Choked by World's Worst Oil Slick, NEw ScIENTIST, Feb. 2, 1991, at 24; T. A. Roberts, Death in the Gulf: A Biologist's View of the Gulf War, BuzzWORM: THE ENVTL. J., May-June 1991, at 52; Charles Sheppard \& Andrew Price, Will Marine Life Survive the Gulf War?, NEW SCIENTIST, Mar. 9, 1991, at 36; Frederick Warner, The Environmental Consequences of the Gulf War, ENVIRONMENT, June 1991, at 6.

39. Several other wars resulted from disputes over natural resources. For example, population pressures in Central Europe, territorial rivalries over the iron-rich Lorraine region, a desire by Germany to gain access to oil, and conflicts over colonies and spheres of influence in resource-rich Africa contributed to the tensions that spurred World War I. Similarly, lack of natural resources fueled Japan's expansionist tendencies prior to World War II. Nearly all of the lesser wars of this century also have had a natural resource component. Conflict over the waters of the Jordan River contributed to the Arab-Israeli War of 1967. France's reluctance to grant Algeria independence, in part because of its rich oil deposits, contributed to the Algerian War of Independence of 1954-62. See Arthur H. Westing, Wars and Skirmishes Involving Natural Resources: A Selection from the Twentieth Century, in GLOBAL REsOuRCES, supra note 34 , at 204-10. 
political system in which nations defend the rights of their citizens. The fragmented political system prevents an integrated, global solution to environmental problems. In many pollution cases, for example, the polluted nation does not have any control over the polluter while the polluter does not have any incentive to curb its pollution because the majority of the damage is external. The institutions that can take action internationally on global environmental problems have limited enforcement powers. This further minimizes the incentive for cooperative action. ${ }^{40}$

By contrast, institutions with enforcement powers, such as national governments, are better regulators. In the United States, for example, the federal government can enforce environmental standards across state lines. Moreover, the absence of tariffs within the United States ensures that resources can be readily redistributed across state lines. As a result, Maine timber can be sold easily in Florida and Florida citrus in Maine. State boundaries seldom bear any significant relationship to ecosystems in the continental United States, but at least resources can flow rather freely across those irrelevant lines. The continent can operate, to some degree, as a political and an ecological unit. Resources flow among the nation states of Europe with more difficulty, but with increasing ease in a common market. They flow with considerably more difficulty among the nation states of Africa. We are still looking for an ethic by which the global commons can be fairly shared in ways that make ecological sense. When nation states are politically operated as if geography and ecology are irrelevant, disaster looms for both nations and nature. Such nations are essentially misfits on their landscapes.

One of the major functions of the United Nations is to keep each nation oriented to global concerns. Since the United Nations is not a sovereign state, its approach must be largely persuasive, negotiatory, and ethical. Its power is based on rights and responsibilities, rather than military force or political power. Its prescriptions are soft laws, but they are aspirational and can orient nations. The U.N. World Charter for Nature, signed by one hundred and twelve states, but not the United States, is guided by the principle that renewable natural resources "shall not be utilized in excess of their natural capacity for regeneration." 41 The U.N. Environment Programme played an

40. See John Dryzek \& Susan Hunter, Environmental Mediation for Intemational Problems, 31 INT'L STUD. Q. 87, 88 (1987). Cf. Daniel Barstow Magraw \& James W. Nickel, Can Today's Intemational System Handle Transhoundary Environmental Problems?, in UPSTREAM/DOWNSTREAM: ISSUES IN ENVIRONMENTAL ETHICS 121 (Donald Scherer ed., 1990) (arguing that "familiar claims about the inherent limits of the international system are exaggerated").

41. World Charter for Nature, G.A. Res. 37/7, U.N. GAOR, 37th Sess., 48th plen. mtg., at $\uparrow$ II.10.d., U.N. Doc. A/37/L.4/Add.1 (1982). See generally WOLFGANG E. BURHENNE \& WILL A. IRWIN, WORLD CHARTER FOR NATURE: LEGISLATIVE HISTORY, COMMENTARY (2d ed. 1986); H. W. Wood, Jr., United Nations World Charter for Nature: The Developing Nations' Initiative To Establish Protections for the Environment, 12 EcoLOGY L. Q. 977 (1985). 
important role in negotiations leading to the 1987 Montreal ozone protocol. ${ }^{42}$ The U.N. International Law Commission has been studying international liability and international watercourses. ${ }^{43}$ The Third U.N. Conference on the Law of the Sea, which produced the U.N. Convention on the Law of the Sea, contributed significantly to a global natural resources dialogue. ${ }^{44}$ The United Nations has facilitated the designation of biosphere reserves. ${ }^{45}$ In all, there are over one hundred and fifty international agreements registered with the United Nations that deal directly with environmental problems. ${ }^{46}$

Much has been done, but there is still much to do. The U.N. Conference on Environment and Development (UNCED) was convened in Rio de Janeiro in June 1992 in the hopes of launching a number of more environmentally responsible international agreements. Delegates from virtually every nation on Earth were there. Unfortunately, national differences constrained the UNCED's attempts to protect the global commons. Concern was ample but cooperation was elusive because nation states defended the interests of their own citizens. This posture pitted nation against nation, and often pitted developed nations against developing nations. Sometimes this conflict of interest arose when developing countries such as Malaysia demanded their rights to exploit their national resources. ${ }^{47}$ More visibly, the United States proved quite unyielding of its national interests and those of its citizens. ${ }^{48}$

42. Montreal Protocol on Substances That Deplete the Ozone Layer, Sept. 16, 1987, U.S.-Can., S. Treaty Doc. No. 100-10, reprinted in 21 INT'L ENV'T REP. 3151 (1988).

43. Daniel B. Magraw, Transboundary Harm: The Intemational Law Commission's Stuty of 'Intemational Liability,' 80 AM. J. INT'L L. 305, 305 (1986).

44. THIRD U.N. CONF. ON THE LAW OF THE SEA, U.N. CONVENTION ON THE LAW OF THE SEA, U.N. Doc. A/CONF.62/122 (1982), reprinted in 21 I.L.M. 1261 (1982). The most relevant environmental portions are extracted in GLOBAL RESOURCES AND INTERNATIONAL CONFLICT, supra note 41, at app. 6. The convention was signed in December 1982 by nearly every country in the world except the United States, but the convention has not yet entered into force because the requisite number of nations $(60)$ have not yet ratified it. However, the United States takes the position that, for the most part, the convention states customary international law. See Robert L. Simon, Troubled Waters: Global Justice and Ocean Resources, in EARTHBOUND: NEW INTRODUCTORY ESSAYS IN ENVIRONMENTAL ETHICS 179 (Tom Regan ed., 1984); William Wertenbaker, A Reporter at Large: The Law of the Sea, NEW YORKER, Aug. 1, 1983, at 38, NEW YORKER, Aug. 8, 1983, at 56.

45. UNESCO publishes a quarterly journal, NATURE AND RESOURCES, interpreting the biosphere reserves program.

46. U.N. ENV'T PROGRAMME, REgister OF INTERNATIONAL TREATIES AND OTHER AGREEMENTS IN THE FIELD OF THE ENVIRONMENT, U.N. Doc. EP/GC.16/Inf.4 (1991).

47. Malaysia steadily defended its right to cut forests, resisting the idea that tropical rainforests were world reserves of biodiversity. Sheila Teff, Malay Forest Fight, CHRISTIAN SCI. MoN., July 2, 1992, at 9, 10. Saudi Arabia steadily sought to weaken if not remove all references in UNCED documents to overconsumption of petroleum resources and the detrimental effects of global warming. Nations Hash Out Details at Summit, DENV. POST, June 14, 1992, at 1A, 5A. Any efforts by developed nations to condition aid or loans on the ecological soundness of development projects were countered with the argument that such conditions violate national sovereignty.

48. President George Bush refused to sign the biodiversity convention. Bush favored protecting biodiversity, but disliked provisions that, he maintained, potentially violated the patent rights of U.S. industry and might cost jobs. Bush found himself facing global issues that needed decade-long solutions a few months away from a national election. Thomas K. Koh, the Singapore diplomat who chaired the Agenda 21 negotiations, remarked, "The United Nations must learn never to hold an international 
The issue of responsibilities to Earth was addressed only subsequently to these national debates, if at all. ${ }^{49}$

Participants initially hoped that four international conventions would be drafted at the UNCED conference: forests, biotechnology, biodiversity, and climate. Only the latter two survived the negotiating process, both in greatly weakened form. The United States pushed for a binding agreement on forests, but was thwarted by the skepticism of developing nations and the Bush administration's deliberately vague position on U.S. old growth forests. The principal stumbling blocks on the biodiversity and biotechnology conventions were the issues of access to genetic resources and technology transfer, both of which forced nations to address the question of who should benefit when valuable natural resources are exploited to make a profit. ${ }^{50}$ When biological

conference during an American election year. " His remark is evidence of how immediate political agendas prevent effective global action by humans seeking a sustainable relationship to and conservation of Earth's biodiversity. Paul Lewis, U.S. at the Earth Summit: Isolated and Challenged, N.Y. TIMES, June 10, 1992, at A6.

49. The Rio Conference considered an inspirational Earth Charter, a short document containing such language as: "Human beings are entitled to live in a sound environment, [in dignity and harmony with nature for which they bear the responsibility for protection and enhancement.]" U.N. GAOR, Preparatory Comm. for UNCED, 4th Sess., Working Group III, Agenda Item 3, at 1, U.N. Doc A/CONF.151/PC/WG.III/L.33 (1992) (brackets in original). Almost every sentence was hotly debated and modified and even the title of the final document was changed to the Rio Declaration on Environment and Development, of which Principle 1 reads: "Human beings are at the centre of concerns for sustainable development. They are entitled to a healthy and productive life in harmony with nature." U.N. CONF. ON ENV'T AND DEV. [UNCED], THE RIO DECLARATION ON ENVIRONMENT AND DEVELOPMENT, at 1, U.N. Doc. A/CONF.151/5/Rev.1 (1992). Developing nations feared the original text over-emphasized responsibility for the natural environment and downplayed their right to develop their national resources.

50. The biodiversity convention presents interesting questions on the ownership of Earth's biota. Historically, native plant species, seeds, and germplasm have been considered to be in the public domain, not owned by any nation. Developing nations are now claiming ownership by country of origin in order to restrict the use of these things by other nations without negotiated compensation. Vandana Shiva complains, "The US . . . has freely taken the biological diversity of the Third World to spin millions of dollars of profits, none of which have been shared with Third World Countries, the original owners of the germplasm." She cites as an example a wild tomato variety (Lycopersicon chmielewskii) taken from Peru in 1962 that was bred into and enhanced the traditional tomato for the U.S. tomato industry, resulting in $\$ 8$ million a year in profits. Peru was paid nothing. Vandana ShIVA, ThE VIOLENCE OF THE GREEN REVOlution: THIRD WORLD AGRICULTURE, ECOLOGY AND POLITICS 260 (1991).

Developing nations also make the contradictory claim that their biological resources are being conserved for the benefit of other nations, and that developed nations ought to pay developing nations for both new conservation measures and the lost opportunity costs of forgoing development. Marlise Simons, North-South Divide is Marring Environment Talks, N.Y. TIMEs, March 17, 1992, at A8; William K. Stevens, Talks Seek to Prevent Huge Loss of Species, N.Y. TMES, March 3, 1992, at B8.

Nonrenewable resources are owned by the nation state in which they happen to be found; in many cases, they are owned by private individuals and corporations within such states. Biotic resources are renewable and less evidently subject to ownership, especially at the species level. Nations and individuals own the forests on their land; farmers own the crops in their fields. However, neither nations nor individuals own species. We pay Saudi Arabia for nonrenewable oil found there, but we do not pay Afghanistan for the use of the bread wheat species (Triticum aestivum) which historically originated there, nor do we pay Mexico for the use of corn (maize, Zea mays), nor Ecuador for tomatoes (Lycopersicon esculentum) and potatoes (Solanum tuberosum). Two of the most widely grown crops in South and Central America are bananas (Musa paradisiaca var. sapientum) and coffee (Coffea arabica). Bananas originated in Malaysia, and coffee in Ethiopia, but nobody pays anything to either of those countries. If the Pacific yew tree (Taxus brevifolia), found in the U. S. Northwest and valuable as a source of taxol, proves to provide a 
resources are assumed to be national possessions in dispute, rather than an Earth commons to be shared, it is difficult to find a fabric in which to share them. In signing the climate convention, most major industrialized nations agreed to set explicit national targets. The principal impediment was the United States' unwillingness to set specific $\mathrm{CO}_{2}$ reduction targets as part of a strategy for stabilizing greenhouse gas emissions by the year 2000 . The United States argued that the risk of detrimental planetary warming was outweighed by the potential for loss of jobs in the United States.

National rights obscure global responsibilities. If the controlling interest is national sovereignty and welfare alone, we may be prevented from implementing an Earth ethics by the fallacy of misplaced community. This fallacy mistakes the nature and character of the communities to which we belong and gives such disproportionate emphasis to some communities that we become blind to others. With wrong premises about community, wrong conclusions and inappropriate actions follow. For example, efforts by developed nations to aid developing nations have been interpreted as foreign aid. Such efforts could better have been interpreted as attempts to save the planet. In that sense, the aid is more a domestic affair for both the donor and recipient nations than a foreign one. National sovereignties divide us when we need deeper solutions which respect larger communities of life on Earth. We are quick to assert our rights; we are slow to face our responsibilities.

cure for cancer, and if it can be grown in the cool climates of Argentina, will the Argentineans owe royalties for the use of the yew to the states of Washington and Oregon, or to the U.S. federal government? President Bush maintained that they will have to pay patents to pharmaceutical companies for any biotechnology that U.S. citizens develop in refining the taxol into a prescription drug.

Jean-Jacques Rousseau warned, "Beware ...., you are lost if you forget that the fruits of the earth belong to everyone, and the earth itself belongs to no one!" JEAN-JACQUES ROUSSEAU, A DISCOURSE ON INEQUALITY 109 (Maurice Cranston ed., 1984) (1754). Rousseau was referring to wild species, which merely happen to be found inside national boundaries, boundaries drawn incidentally to the location of such species. Taken from their initial locations, such species are subsequently grown elsewhere. We do pay for those productive labors. Where labor has been deliberately expended to alter a native wild type, as is done by plant breeders, the laborer is worthy of his work.

The U.N. Food and Agriculture Organization (FAO) has produced several documents on the ethics of genetic resource transfer among nations. See FAO, Commission on Plant Genetic Resources, Draft International Code of Conduct for Plant Germplasm Collecting and Transfer, April 15-19, 1991. The United Nations has declared "the right of peoples and nations to permanent sovereignty over their natural wealth and resources," and that this right "must be exercised in the interest of their national development and of the well-being of the people of the State concerned." G.A. Res. 1803, U.N. GAOR, 17th Sess., 1194th plen. mtg., at $\Upsilon$ I.1, U.N. Doc. A/5344/Add.1 (1962); see also GeORGE ElIAN, THE PRINCIPLB OF SOVEREIGNTY OVER NATURAL RESOURCES (Andrei Bantas trans., 1979); Nico H. Schrijver, Permanent Sovereignty over Natural Resources versus the Common Heritage of Mankind: Complementary or Contradictory Principles of International Economic Law?, in INTERNATIONAL LAW AND DEVELOPMENT 87 (Paul De Wart et al. eds., 1988).

The biodiversity convention is thus surrounded by serious global, long-term issues about the ownership of plant and animal resources, about the common heritage of humankind versus nationalized natural resources, about patents for the discoveries of new uses for biotic resources, about who owns what, and about what is a fair distribution of the benefits of biodiversity. Bush became the villain at Rio because the United States was the main holdout on the biodiversity convention. Politics fragmented serious efforts to work toward consensus on planetary biodiversity issues. 
The oceans illustrate our entwined destinies. Almost all the global land area is claimed by sovereign nations. These nations also claim territorial waters, but the high seas belong to no nation, nor do their fauna and flora. It is going to be difficult to reduce the sense of sovereignty on land. The oceans may be a good sphere in which to emphasize that some things belong to no one because they belong to us all. After all, the oceans cover seventy percent of the Earth's surface and are critical to the health of the planet.

The surprisingly comprehensive treaty produced by the Third U.N. Conference on the Law of the Sea is a harbinger of how the oceans can unite nations. ${ }^{51}$ The conference was dominated by the idea that the oceans are part of the common heritage of humankind. That concept provides a good beginning for developing a consciousness of our common heritage in land and air.

Perhaps we are ready now for a U.N.-initiated Conference on the Law of the Atmosphere. The air, like the sea, is not owned by any nation, although nations do control the airspace over their territories. There was rather surprising agreement on the reduction of chlorofluorocarbons at Montreal, though we have yet to see how fully operational these agreements will become. Agreements on global warming will be much harder to implement, because of the difficulty of $\mathrm{CO}_{2}$ containment. There is, however, only one atmosphere, and every nation needs this atmosphere to survive. Wildlife needs the atmosphere as much as humans; in turn, plant life recycles the atmosphere through the carbon dioxide and oxygen cycle. There is no better example of a commons in which we all have entwined destinies.

Nor does this sense of entwined destinies need to remain only at the prudential, national, or even anthropocentric level. To illustrate this we may return to the sea. The International Whaling Commission (IWC) was established in 1946 to benefit an endangered industry, which required the cooperation of the whaling nations. These nations at first cooperated in their own interests, hoping to share an ongoing resource in which they had entwined destinies. Over the years the goal of the IWC changed; today its goal is to save endangered whale species. The IWC recognized that these majestic species, who had lived for so long in the marine ecosystems, could no longer survive without constraints on human commerce. The emphasis of the commission shifted over the years from commerce that was to the advantage of the mutually consenting nations to conservation and even preservation of the whales, with growing sympathy for the whales themselves, even if such measures were against the commercial advantage of the nations involved..$^{52}$

51. See supra note 44 and accompanying text.

52. Patricia Birnie, The Role of Developing Countries in Nudging the International Whaling Commission from Regulating Whaling to Encouraging Nonconsumptive Uses of Whales, 12 ECOLOGY L.Q. 
The idea of wildlife as both common heritage and good in itself has also produced a number of treaties that involve migratory birds, ivory, animal skins, and plant products. For example, the World Charter for Nature affirms that "every form of life is unique, warranting respect regardless of its worth to man. "153 These agreements help start us toward an Earth ethics. After the Law of the Sea and the Law of the Atmosphere, we might be ready for a U.N.-sponsored Law of World Wildlife. The Climate and the Biodiversity Conventions both contain many sections that need to be filled out through ongoing negotiations. Reaching international consensus involves compromise, but the process of compromise involves the larger community of humans and of fauna and flora in terrestrial and marine ecosystems; the very recognition of this larger community is a step in the direction of an Earth ethics. The United States' national motto is E pluribus unum. We should elevate this motto to a world in which we have entwined destinies.

\section{National Citizens and Native Residents on Earth}

Real community does not yet exist at the world level. Nevertheless, humans live on only one Earth and our powers operate at global levels. We must therefore begin to see Earth globally and to see ourselves as Earth residents with transnational interests. When we hear the word international, we typically think of domestic versus foreign interests. The word global, however, does not bring forth distinctions between domestic and foreign. We are all natives of the Earth. The animal who builds a polis still inhabits an oikos, a whole world. We are natives, naturally born on Earth, before we are nationals, citizens of a political state. The human is first and always an Earthling.

The natural and the cultural on Earth have entwined destinies. There were no humans on Earth across great reaches of geological time. Instead, Earth was entirely a natural system. For several thousand years, Earth has increasingly supported cultural systems. In the last few centuries, these cultural systems have grown exponentially. Today, again and again, cultural systems organized as nation-states press Earth's natural systems to their carrying capacities. In such situations, the system of sovereign states can make it difficult to achieve cooperation. Often the changes in the ecosphere are incremental and we awake to them too late. However, the threat to natural systems at the planetary level can produce consensus because nations now have a common interest that is entwined with the integrity of natural systems on the whole planet.

937 (1985); James E. Scarff, Intemational Management of Whales, Dolphins, and Porpoises: An Interdisciplinary Assessment, 6 ECOLOGY L.Q. 323 (pt. 1) \& 571 (pt. 2) (1977).

53. World Charter for Nature, supra note 41 , at Preamble. 
The Earth is one, but its cultures are myriad. Diversity contributes to the richness of our planet, but it can also be divisive. The variety of cultures makes it difficult to reach common accord, even when different cultures have a common interest in maintaining the natural systems that support them. The basic problem is that power is decentralized into national and subnational units. These political units may have little or no intelligent relationship to geography and ecology. ${ }^{54}$ Regionalism in environmental policy can be beneficial, but only if the regional focus is as geographical and ecological as it is political, and only if the region is aware of its global connections. The operative values tend to become fragmented, political, and economic. The needed values are global, ethical, and ecological.

The view from space gives us a global vision, but we have yet to make it operational on the home planet. The view from space eliminates boundaries. Earth is seen as a seamless dynamic whole. Astronauts have sensed this expanding perception: "The first day we all pointed to our countries. The third or fourth day we were pointing to our continents. By the fifth day we were aware of only one Earth. "55 "From space I saw Earth - indescribably beautiful with the scars of national boundaries gone. ${ }^{.56}$

In an earlier era, an educated person was one who understood and acted upon the privileges, rights, and responsibilities of citizenship. Today, an educated person must understand and do far more. It is not enough to be a good national or international citizen, because neither of those terms take sufficient account of nature. "Citizen" captures only half the truth; the other half is that we are residents dwelling on landscapes. We are natives on Earth. Our responsibility to Earth might be thought the most remote of our responsibilities. It seems so grandiose and vague beside our concrete responsibilities to our children or next door neighbors. It is, however, far more important in the long run. Our responsibility to Earth is the most fundamental and the most comprehensive of our responsibilities. We can hardly be responsible to anything more cosmic - except perhaps to God.

\section{ETHICS ON THE HoMe Planet}

An ethics about dirt? That idea is sometimes taken to be the ultimate reductio ad absurdum in environmental ethics. Put like that it is hard to disagree. A clod of dirt, which is just some earth (spelled with a lower case

54. Consider, for example, the shape of the state of Colorado, a big rectangle in the middle of the American continent. Colorado is a political unit whose boundaries have nothing whatsoever to do with the regional ecology on which Coloradoans need to establish a sustainable culture, using, among other scarce resources, the waters of the Colorado River.

55. THE HOME PLANET 116 (Kevin W. Kelley ed., 1988) (above photograph 82).

56. Id. at 109 (opposite photograph 76). 
"e"), has no intrinsic value, nor do we have duties to it. ${ }^{57}$ Yet when we go from earth to Earth, from dirt to the prolific planetary system of which it is part, perspectives change. ${ }^{58}$ Earth is Mother Earth, the womb out of which we come and which we never really leave. Dealing with an acre or two of real estate, perhaps even with hundreds or thousands of acres, we can think that it belongs to us. On the global scale, however, Earth is not something we own. Earth does not belong to us; rather, we belong to it. We belong on it. The'question is not of property, but of community. The vision of human life we ought to aspire to is not that of maximum exploitation of Earth as a big property resource, but that of a valued residence in a created community of life.

When we say that Earth is valuable, in a humanistic sense, we mean that it is a resource for people who are able to value it instrumentally in a variety of ways. Earth is so valuable that humans have a right to an environment with integrity. When we say that Earth is valuable in an ecological sense, we mean that Earth is able to produce value, and has long been doing so as an evolutionary ecosystem. Humans are a late though remarkable product of the evolutionary process. Humans find Earth valuable, able to satisfy preferences, able to produce valued experiences. Subjective value events are a subset of the larger, objective production and support of natural values. Our responsibility is to define our role in both benefiting from and conserving this community of life in which we reside.

In that sense, an Earth ethics is not the reductio ad absurdum of silly and peripheral concerns about chipmunks and daisies, extrapolated to rocks and

57. Dirt has, of course, great instrumental value. Humanity's ethics toward other humans can and does involve dirt. Good clean soil supports life. Polluted soil poisons life.

58. An isolated piece of dirt has no intrinsic value in and of itself. But a handful of dirt is integrated into an ecosystem. Earth is a part, Earth the whole. Dirt is product and process in a system to which we do have responsibilities. Edward $O$. Wilson writes:

Think of scooping up a handful of soil and leaf litter and placing it on a white cloth - as a field biologist would do - for closer examination. This unprepossessing lump contains more order and richness of structure, and particularity of history, than the entire surface of all the other (lifeless) planets. It is a miniature wilderness that would take almost forever to explore, should we choose to make the organisms in it the objects of serious biological study. Every species living there is the product of millions of years of history, having evolved under the harshest conditions of competition and survival. Each organism is the repository of an immense amount of genetic information.

The abundance of the organisms increases downward, according to size, like layers in a pyramid. The handful of soil and litter is home for dozens of insects, mites, nematode worms, and other small invertebrates, most of which are just visible to the naked eye. There are also about a million fungi and ten billion bacteria, mostly microscopic. Each of the species has a distinct life cycle fitted to a portion of the micro-environment in which it thrives and reproduces. The individuality of each is programmed by an exact sequence of nucleotides, the ultimate molecular units of the genes. These species have evolved as independent elements for thousands of generations.

Edward O. Wilson, An Introduction, NATURE ConservaNCY NEWs, Nov.-Dec. 1983, at 4. See also EDWARD O. WILSON, BIOPHILIA 13-17 (1984). Wilson refers to only a handful of dirt; how much more must be the value of a planet full of dirt. 
dirt. To the contrary, it is the elevation to ultimacy of an urgent world vision. A century ago, calls for community were typically phrased as the brotherhood of man and the fatherhood of God. Now such a call must be more ecological, less paternalistic, a call for appropriate respect for this home planet.

Critics of the space program feared that space flights were an act of human arrogance, of hubris in the extreme, and an extension of the conquest and dominion by Homo sapiens that has already ravaged the planet. Instead, people responded unexpectedly. The high and the mighty of spirit failed to materialize with the flight into space. Rather, humility, from humus (which means earthy and is also the root of human), was the dominant experience. The repeated reaction was a recognition of the value and beauty of the home planet and our destiny in caring for it. Perhaps there is truth in the beatitude, "Blessed are the meek, for they shall inherit the Earth." Earth is indeed a planet with promise, a promised planet, and we humans have both the right to share in it and the responsibility to help preserve that promise. 
- 